\title{
Summer Symphony
}

\author{
Elizabeth Cruickshank
}

2nd Vice Pres. S.N.H.S.

The full-foliaged month of June being also the home month for birds is our favorite time at the lake. Near our rain barrel eight varieties of nests were, or had been, occupied. Finches fed little balls of gold at our door. A busy little fly-catcher, coughing its "chebec, chebec" built a nest of plant down in the crotch of a choke cherry tree at our window. How neat a little home this was compared with the platform of twigs carelessly thrown together by mourning doves a few feet away. A week in the cherry company of so many birds went much too fast.

Judy had a surprise for us on one of our trips to the valley. There was a bog in their new pasture. To reach it we walked through fields of fleecy pyramids of meadow sweet. We passed a sea of gold, a slough transformed by bladderwort. Contemplating its way of life, the numerous bladders on its threadlike leaves keeping the plant afloat with its burden of beautiful bloom while trapping tiny water animals for food inspired in us as always a humble spirit before the handi work of the Great Designer.

On the pasture slope, like fragments dropped from the summer sky, were mats of gentians, oblong leaved. Meadow blazing star with their gorgeously rich red-purple flowerheads and strikingly shingled involucres, were stunning besides everlasting and owl's clover.

A cow path led through the thicket of poplar and willow. If flowers enjoy the air they breath; as birds enjoy the song they sing, they must have loved this air so laden with the fragrance of mint and warm so ft earth. Here were new friends, a Lapland of discovery for Judy, while memories of "the dear dead days beyond recall" down East, were poignantly revived for her grandmother.

Gossamer webs, glistening with drops like dew, funnelled over the hum- mocks. Green-flowered orchids and deep pink wintergreen enjoyed the shade, while in happy coinpany were woodsorrel, fringed loosestrife, zizia, lobelia, grass of parnassus (always facing heavenward) buttercups, bog violets, shining arnica and the smaller fringed gentian with its classical vase shaped corolla when open, twisted when closed. Arrow, bluestem and cotton grasses neighbored other varieties of rush and grass. Frogs of all sizes hid in every cosy hollow. Odd pieces of diamond willow were gathered for next winters homework.

On the valley road badgers and skunks crossed our path. Flocks of yellow headed blackbirds flew over the little ponds in the flats crowded with mudhens, their white bills sparkling. With the raising and lowering of the water level in the lake we wondered how many baffled little creatures perished, But, life is changed.

On Judy's home pas ture hill we found a clump of white among the purple bergarnot and new to us too, conetlower with ray flowers of rich maroon velvet. Deer mice with their silky white shirt fronts hopped over a fallen stump as we climbed to the hilltop. Here, as from a windowsill of heaven, we viewed the pageantry of the world below in its high summer grooming. Gardens were peoms of colour harmony; patches of fields shining with gumweed, edged blue fields of flax. Waving fields of oats, tall fields of barley, their bearded heads drooping, fields of alfalfa, weighted with bees, all seemed incidental on the plains beside the miles and miles of wheat, now gold and ready for harvest.

Never more than fifty miles from home everywhere we were conscious of the warm and melodious symphony of sounds and sights of a summer that to us has been a.memorable one. 